\title{
Musculoskeletal and neurological manifestations in a cohort of Egyptian Familial Mediterranean fever patients: genotype- phenotype correlation
}

\author{
Mohamed H. Ahmed ${ }^{1}$, Amira M. Ibrahim²º, Salma M. Ragab ${ }^{3}$ and Ayah M. Mahros ${ }^{1}$
}

\begin{abstract}
Background: Familial Mediterranean Fever (FMF) is a periodic auto-inflammatory disease with multiple systemic manifestations. This study aims to describe the various musculoskeletal and neurological manifestations in a cohort of Egyptian FMF patients and to evaluate their relation to the different Mediterranean fever gene (MEFV) mutations.

Results: This study involved 145 FMF patients, of them $62.1 \%$ were females and $31.7 \%$ were of the pediatric age. All involved patients had homozygous MEFV gene mutation. The presenting manifestation in $71.9 \%$ of these patients was abdominal pain followed by musculoskeletal manifestations in $35.2 \%$ of them. $38.6 \%$ of the involved patients had arthritis during the period of follow-up. Monoarthritis was the most frequent pattern of arthritis. Arthralgia was present in $96.6 \%$ of the studied patients. Myalgia was present in $19.3 \%$ of the studied patients especially involving the lower limb muscles with one case of protracted febrile myalgia. Neurological manifestations were present in about $86.9 \%$ of patients with vertigo, paresthesia, and seizures as the most common. Five major MEFV gene mutations were found in most of the studied patients (135 patients): M694V, M680I, E148Q, V726A, and M694I. When a comparative study was done between these five major mutations according to the age of onset of the symptoms, different musculoskeletal and neurological manifestations, ESR, serum amyloid level and dose of colchicine, no statistical difference was found.
\end{abstract}

Conclusion: Musculoskeletal manifestation is the second most common presenting symptom in a cohort of Egyptian FMF patients after abdominal pain. Arthralgia is the most frequent musculoskeletal manifestation while monoarthritis of the knee or ankle joint is the most common pattern of arthritis in FMF patients. Vertigo, paresthesia, and seizures are the most frequent neurological manifestations. Musculoskeletal manifestations, neurological manifestations, serum amyloid level, and dose of colchicine are not related to the type of the genetic mutation in this cohort.

Keywords: Egyptian, Familial Mediterranean fever, Genotype, Musculoskeletal, Neurological manifestations

\section{Background}

Familial Mediterranean fever (FMF) is an autosomal recessive hereditary disorder that is particularly frequent in Turkish, Armenian, Jewish, and Arabic communities

\footnotetext{
*Correspondence: amiraibrahim1110@gmail.com

2 Physical Medicine, Rheumatology and Rehabilitation Department,

Faculty of Medicine, Kafrelsheikh University, Kafrelsheikh, Egypt

Full list of author information is available at the end of the article
}

$[1,2]$. It is the most common member of the family of monogenic autoinflammatory disorders. It is due to mutations in the Mediterranean fever (MEFV) gene, which encodes pyrin, a protein that plays a role in the regulation of both inflammation and apoptosis [3-5].

Familial Mediterranean fever is characterized by relapsing and remitting episodes of one to three days of fever, sterile serositis, arthritis, and an erysipeloid erythematous rash with elevations of serum inflammatory 
markers [6, 7]. Serositis most commonly presents as sterile peritonitis, although, pleuritis and pericarditis may also be present $[8-10]$.

The arthritis of FMF is usually in the form of acute attacks of pain and swelling, most frequently affecting large joints of the lower extremities, although the shoulder, sternoclavicular or temporomandibular joints may also be involved. These attacks usually disappear within 2-3 days, and despite recurrent episodes of arthritis, there are no permanent sequelae of the affected joints. However, in about $5 \%$ of the patients, protracted arthritis develops, almost involving the hips or knees. Although complete recovery is the rule, disabling joint damage can occur and even may lead to joint replacement [1116]. Myalgia is also a common manifestation of FMF and occurs in about $20 \%$ of patients. Protracted febrile myalgia syndrome is a unique syndrome, that has been described in patients with FMF, characterized by severe, disabling muscle pain and tenderness lasting several weeks, which responds only to corticosteroid therapy [17, 18].

Although FMF is a polyserositis disease, there is also central nervous system (CNS) involvement and many associated neurological manifestations. The pathogenesis of CNS involvement is unclear and is a subject of debate. Demyelinating lesions, septic meningitis, and pseudotumor cerebri have been reported in FMF patients [19, 20].

The diversity of the clinical manifestations of FMF can often delay the diagnosis. To date, the identification of the FMF gene and its various mutations provides the application of an accessible, non-invasive, and sensitive molecular genetic test for an accurate diagnosis of this fascinating disease [21]. The location of the MEFV gene has been mapped on the short arm of chromosome 16 at position 13.3 (16p13.3) with about 280 mutations have been described for FMF, nine of them(E167D,T267I, M694V, V726A, M680I, M694I, R761H, A744S, I692del) are clearly pathogenic while the most frequent MEFV gene mutations are M694V, V726A, E148Q, M680I, and M694I respectively [22, 23]

The aim of the current work is to describe the various musculoskeletal and neurological manifestations in a cohort of Egyptian FMF patients and to evaluate their relation to the different MEFV gene mutations Tables 1 , $2,3,4,5,6$ and 7 .

\section{Methods}

In this retrospective study, the medical records of all FMF patients (diagnosed according to Tel-Hashomer criteria [24]) under follow-up at the outpatient clinics of our University hospitals through the period from June 2018 to July 2021, were included. 145 patients were involved. We described the musculoskeletal and neurological features
Table 1 Distribution of the studied cases according to different demographic and clinical parameters $(n=145)$

No. (\%)

\begin{tabular}{ll}
\hline $\begin{array}{l}\text { Age at time of the study } \\
\quad<16\end{array}$ & $46(31.7 \%)$ \\
16:40ys & $99(68.3 \%)$ \\
Sex & \\
$\quad$ Male & $55(37.9 \%)$ \\
$\quad$ Female & $90(62.1 \%)$ \\
Age of onset of symptoms & \\
Median (Min. - Max.) & $16(1-40)$ \\
Age of gene testing & \\
Median (Min. - Max.) & $24(3-64)$ \\
presenting manifestations & \\
Abdominal pain & $104(71.7 \%)$ \\
Fever & $41(28.3 \%)$ \\
Musculoskeletal manifestations & $51(35.2 \%)$ \\
Fever & $3(2.1 \%)$ \\
Headache & $12(8.3 \%)$ \\
Neurological manifestations & \\
Disorientation & $3(2.1 \%)$ \\
Syncope & $14(9.7 \%)$ \\
Recurrent meningitis & $14(9.7 \%)$ \\
Vertigo & $33(22.8 \%)$ \\
Tremor & $13(9 \%)$ \\
Cerebrovascular disorders & $1(0.7 \%)$ \\
Ataxia & $5(3.4 \%)$ \\
Seadache & $5(3.4 \%)$ \\
Pseudotumor cerebri & $18(12.4 \%)$ \\
Paresthesia & $13(9 \%)$ \\
Non -neurological symptoms & $22(15.2 \%)$ \\
Msculosk & $19(23.1)$
\end{tabular}

Musculoskeletal manifestations

Arthralgia

Absent

$5(3.4 \%)$

Low back pain $\quad 29(20 \%)$

Knee joints $\quad 37(25.5 \%)$

Feet joints $29(20 \%)$

ankles joints $\quad 32(22.1 \%)$

Shoulder joints $\quad 11(7.6 \%)$

Chest pain $1(0.7 \%)$

Wrist and small hand joints $\quad 13(9 \%)$

Myalgia

$28(19.3 \%)$

Protracted febrile myalgia $\quad 1(0.7 \%)$

Lower limb muscles $\quad 14$ (9.7\%)

Upper limb muscles 10 (6.9\%)

Upper and lower limb muscles $\quad 3(2.1 \%)$

Arthritis

Absent $\quad 84(57.9 \%)$

Knee $24(16.6 \%)$

Feet joints $10(6.9 \%)$

Ankle Joints $\quad 12(8.3 \%)$ 
Table 1 (continued)

\begin{tabular}{ll}
\hline & No. (\%) \\
\hline Wrist and hand & $7(4.8 \%)$ \\
Pattern of arthritis & \\
Monoarthritis & $39(26.9 \%)$ \\
Oligoarthritis & $11(7.6 \%)$ \\
$\quad$ Polyarthritis & $11(7.6 \%)$ \\
Colchicine dose at diagnosis & \\
0.5:1 mg & $28(19.3 \%)$ \\
1.5:3mg & $117(80.7 \%)$ \\
Current colchicine dose & \\
0.5:1 mg & $20(13.8 \%)$ \\
1.5:3mg & $125(86.2 \%)$ \\
Cause of colchicine dose increase & $144(99.3 \%)$ \\
$\quad$ Musculoskeletal manifestations & $46(31.7 \%)$ \\
Abdominal pain & $71(49 \%)$ \\
Increased fever duration & $36(24.8 \%)$ \\
Serum Amyloid A & \\
$<6$ (normal) & $17(12.1 \%)$ \\
$>6$ (Abnormal) & $123(87.9 \%)$ \\
Median (Min. - Max.) & $36.1(1.9-215)$ \\
\hline SD Standard deviation &
\end{tabular}

SD Standard deviation

Table 2 Distribution of the studied cases according to types of MEFV gene mutation $(n=145)$

\begin{tabular}{ll}
\hline Types of genetic mutation & No. (\%) \\
\hline M694V & $39(26.9 \%)$ \\
A744S & $1(0.7 \%)$ \\
V726A & $20(13.8 \%)$ \\
M680I & $37(25.5 \%)$ \\
E148Q & $25(17.2 \%)$ \\
A744I & $2(1.4 \%)$ \\
M694I & $14(9.7 \%)$ \\
R202Q & $4(2.8 \%)$ \\
K695R & $1(0.7 \%)$ \\
E167D & $2(1.4 \%)$ \\
\hline
\end{tabular}

of these patients, in whom genetic screening revealed homozygosity for the MEFV gene. MEFV gene mutation was detected using several multiplex Real-Time PCR reactions. Any patient with associated rheumatologic or neurologic diseases as juvenile idiopathic arthritis, rheumatoid arthritis, spondarthropathies, demyelinating disease, or hereditary neuropathy were excluded. We also reported the correlations between the musculoskeletal manifestations, neurological manifestations, and other features of the disease with the type of MEFV gene mutation.

\section{Data collection}

The following data were retrieved from the records of eligible patients: demographics characteristics, disease presentation, different musculoskeletal and neurological manifestations, ESR and serum amyloid A level during the last follow-up visit of the patients, colchicine dose at disease onset and currently and the type of MEFV gene mutation.

\section{Statistical Analysis}

Data were fed to the computer and analyzed using IBM SPSS software package version 20.0. (Armonk, NY: IBM Corp). The Kolmogorov- Smirnov was used to verify the normality of distribution of variables, Comparisons between groups for categorical variables were assessed using the Chi-square test (Monte Carlo). Mann Whitney test was used to compare between two groups for not normally distributed quantitative variables. The significance of the obtained results was judged at the $5 \%$ level

\section{Results}

This study involved 145 FMF patients, of them $62.1 \%$ were females and $31.7 \%$ were in the pediatric age. The presenting manifestation in $71.9 \%$ of these patients was abdominal pain followed by musculoskeletal manifestations in $35.2 \%$ of them in the form of arthralgia, myalgia, and arthritis, to be followed by fever in $30.4 \%$.

Regarding the musculoskeletal manifestations, $38.6 \%$ of the involved patients had arthritis during the period of follow-up. The most commonly affected joints were the knee and ankle, the small joints of the feet, and the

Table 3 Comparison between the different types of MEFV gene mutation according to the presenting manifestation

\begin{tabular}{|c|c|c|c|c|c|c|c|}
\hline & $\begin{array}{l}\text { Total }(n=135) \\
\text { No. }(\%)\end{array}$ & $\begin{array}{l}\text { M694V ( } n=39) \\
\text { No. (\%) }\end{array}$ & $\begin{array}{l}\text { V726A }(n=20) \\
\text { No. }(\%)\end{array}$ & $\begin{array}{l}\text { M6801 ( } n=37) \\
\text { No. }(\%)\end{array}$ & $\begin{array}{l}\text { E148Q }(n=25) \\
\text { No. }(\%)\end{array}$ & $\begin{array}{l}M 694 I(n=14) \\
\text { No. }(\%)\end{array}$ & $\mathrm{p}$ \\
\hline \multicolumn{8}{|c|}{ The presenting manifestation } \\
\hline Abdominal pain & $97(71.9 \%)$ & $26(66.7 \%)$ & $12(60 \%)$ & $26(70.3 \%)$ & $20(80 \%)$ & $13(92.9 \%)$ & 0.212 \\
\hline Fever & $41(30.4 \%)$ & $12(30.8 \%)$ & $5(25 \%)$ & $10(27 \%)$ & $9(36 \%)$ & $5(35.7 \%)$ & 0.904 \\
\hline $\begin{array}{l}\text { Musculoskeletal } \\
\text { manifestations }\end{array}$ & $45(33.3 \%)$ & $8(20.5 \%)$ & $9(45 \%)$ & $16(43.2 \%)$ & $8(32 \%)$ & $4(28.6 \%)$ & 0.206 \\
\hline
\end{tabular}


Table 4 Comparison between the different types of MEFV gene mutation according to the age of onset and serum amyloid A

\begin{tabular}{|c|c|c|c|c|c|c|}
\hline & Total & M694V & V726A & M6801 & E148Q & M694I \\
\hline Age at the start of symptoms & $(n=135)$ & $(n=39)$ & $(n=20)$ & $(n=37)$ & $(n=25)$ & $(n=14)$ \\
\hline Median (Min. - Max.) & $16(1-40)$ & $15(5-35)$ & $17(5-39)$ & $18(1-38)$ & $18(2-40)$ & $16.5(12-40)$ \\
\hline Mean \pm SD & $17.5 \pm 9.2$ & $16.8 \pm 8.5$ & $17.1 \pm 8.5$ & $19.1 \pm 9.8$ & $17.4 \pm 11.1$ & $18.2 \pm 7.6$ \\
\hline (p) & & $(0.544)$ & $(0.938)$ & $(0.209)$ & $(0.789)$ & $(0.695)$ \\
\hline Serum Amyloid A & $(n=130)$ & $(n=37)$ & $(n=20)$ & $(n=37)$ & $(n=24)$ & $(n=12)$ \\
\hline Median (Min. - Max.) & $36.1(1.9-215)$ & $33.9(3-186)$ & $36.1(4.7-214)$ & $49.7(3-186)$ & $28.4(3-177)$ & $30.5(1.9-168)$ \\
\hline Mean $\pm S D$ & $59.4 \pm 58.5$ & $58.2 \pm 59.7$ & $71.6 \pm 64.8$ & $63.1 \pm 51.8$ & $55.4 \pm 56.5$ & $46.6 \pm 46.9$ \\
\hline (p) & & $(0.719)$ & $(0.370)$ & $(0.212)$ & $(0.778)$ & $(0.569)$ \\
\hline
\end{tabular}

SD Standard deviation U: Mann Whitney test

$p p$ value for comparing between the different types of genetic mutation

Table 5 Comparison between the different types of MEFV gene mutation according to Colchicine dose and ESR level

\begin{tabular}{|c|c|c|c|c|c|c|c|}
\hline & $\begin{array}{l}\text { Total }(n=135) \\
\text { No. }(\%)\end{array}$ & $\begin{array}{l}\text { M694V ( } n=39) \\
\text { No. (\%) }\end{array}$ & $\begin{array}{l}\text { V726A }(n=20) \\
\text { No. }(\%)\end{array}$ & $\begin{array}{l}\text { M6801 ( } n=37) \\
\text { No. (\%) }\end{array}$ & $\begin{array}{l}\text { E148Q }(n=25) \\
\text { No. }(\%)\end{array}$ & $\begin{array}{l}\text { M694I }(n=14) \\
\text { No. }(\%)\end{array}$ & $\mathrm{p}$ \\
\hline \multicolumn{8}{|c|}{ Colchicine dose at diagnosis } \\
\hline $1.5: 3 \mathrm{mg}$ & $110(81.5 \%)$ & $31(79.5 \%)$ & $17(85 \%)$ & $31(83.8 \%)$ & $18(72 \%)$ & $13(92.9 \%)$ & ${ }^{M C_{p}}=0.607$ \\
\hline \multicolumn{8}{|c|}{ Colchicine dose now } \\
\hline $1.5: 3 \mathrm{mg}$ & $117(86.7 \%)$ & $34(87.2 \%)$ & $17(85 \%)$ & $32(86.5 \%)$ & $21(84 \%)$ & $13(92.9 \%)$ & ${ }^{M C_{p}}=0.970$ \\
\hline \multicolumn{8}{|l|}{ ESR } \\
\hline $10-20$ & $12(8.9 \%)$ & $2(5.1 \%)$ & $2(10 \%)$ & $5(13.5 \%)$ & $2(8 \%)$ & $1(7.1 \%)$ & ${ }^{M C} C_{p}=0.804$ \\
\hline $20-50$ & $77(57 \%)$ & $20(51.3 \%)$ & $10(50 \%)$ & $21(56.8 \%)$ & $15(60 \%)$ & $11(78.6 \%)$ & ${ }^{M C_{p}}=0.450$ \\
\hline $50-100$ & $43(31.9 \%)$ & $15(38.5 \%)$ & $8(40 \%)$ & $11(29.7 \%)$ & $7(28 \%)$ & $2(14.3 \%)$ & $M C_{p}=0.458$ \\
\hline
\end{tabular}

$\mathrm{X}^{2}$ : Chi square test MC: Monte Carlo

$p p$ value for comparing between the different types of genetic mutation

*: Statistically significant at $p \leq 005$

Table 6 Comparison between the different types of MEFV gene mutation according to different Musculoskeletal manifestations

\begin{tabular}{|c|c|c|c|c|c|c|c|}
\hline & $\begin{array}{l}\text { Total }(n=135) \\
\text { No. }(\%)\end{array}$ & $\begin{array}{l}\text { M694V ( } n=39) \\
\text { No. }(\%)\end{array}$ & $\begin{array}{l}\text { V726A }(n=20) \\
\text { No. }(\%)\end{array}$ & $\begin{array}{l}\text { M6801 }(n=37) \\
\text { No. }(\%)\end{array}$ & $\begin{array}{l}\text { E148Q }(n=25) \\
\text { No. }(\%)\end{array}$ & $\begin{array}{l}\text { M694I }(n=14) \\
\text { No. }(\%)\end{array}$ & $p$ \\
\hline \multicolumn{8}{|l|}{ Arthralgia } \\
\hline Low back pain & $24(17.8 \%)$ & $9(23.1 \%)$ & $4(21.1 \%)$ & $5(13.9 \%)$ & $4(16.7 \%)$ & $2(15.4 \%)$ & ${ }^{M C_{p}}=0.850$ \\
\hline Knee & $34(25.2 \%)$ & $6(15.4 \%)$ & $6(31.6 \%)$ & $13(36.1 \%)$ & $6(25 \%)$ & $3(23.1 \%)$ & ${ }^{M C} p=0.367$ \\
\hline Feet & 25 (18.5\%) & $9(23.1 \%)$ & $4(21.1 \%)$ & $6(16.7 \%)$ & $4(16.7 \%)$ & $2(15.4 \%)$ & ${ }^{M C} p=0.939$ \\
\hline Ankle & $32(23.7 \%)$ & $10(25.6 \%)$ & $4(20 \%)$ & $8(21.6 \%)$ & $6(24 \%)$ & $4(28.6 \%)$ & ${ }^{M} c_{p}=0.088$ \\
\hline Wrist and hand & 12 (8.9\%) & $2(5.1 \%)$ & $3(15.8 \%)$ & $2(5.6 \%)$ & $3(12.5 \%)$ & $2(15.4 \%)$ & ${ }^{M C_{p}}=0.476$ \\
\hline Arthritis & 55 (40.7\%) & $16(41 \%)$ & $5(25 \%)$ & $21(56.8 \%)$ & $8(32 \%)$ & $5(35.7 \%)$ & $M C_{p}=0.140$ \\
\hline Myalgia & $28(19.3 \%)$ & $8(20.5 \%)$ & $5(25 \%)$ & $7(18.9 \%)$ & $5(20 \%)$ & $3(21.4 \%)$ & ${ }^{M C_{p}}=0.247$ \\
\hline
\end{tabular}

MC Monte Carlo

hands respectively. Monoarthritis was the most frequent pattern of arthritis, being present in 26.9\% (39 patients) of the studied patients. Arthralgia was the most prominent musculoskeletal manifestation, presenting in 96.6\% of the studied patients with also the knee as the most frequent joint, followed by the ankle, feet, and lower back respectively. Myalgia was present in $19.3 \%$ of the studied patients (28 patients) involving the lower limb muscle (14 patients), upper limb muscles (10 patients), upper and lower limb muscles (3 patients) with one case of protracted febrile myalgia.

As regards the neurological manifestations, they were present in about $86.9 \%$ of cases throughout the period of follow up. Vertigo was the most common manifestation 
Table 7 Comparison between the different types of MEFV gene mutation according neurological manifestations

\begin{tabular}{|c|c|c|c|c|c|c|c|}
\hline & $\begin{array}{l}\text { Total }(n=135) \\
\text { No. }(\%)\end{array}$ & $\begin{array}{l}\text { M694V }(n=39) \\
\text { No. }(\%)\end{array}$ & $\begin{array}{l}\text { V726A }(n=20) \\
\text { No. }(\%)\end{array}$ & $\begin{array}{l}\text { M6801 }(n=37) \\
\text { No. }(\%)\end{array}$ & $\begin{array}{l}\text { E148Q }(n=25) \\
\text { No. }(\%)\end{array}$ & $\begin{array}{l}\text { M694I }(n=14) \\
\text { No. }(\%)\end{array}$ & $p$ \\
\hline Syncope & $14(10.4 \%)$ & $4(10.3 \%)$ & $3(15 \%)$ & $3(8.1 \%)$ & $2(8 \%)$ & $2(14.3 \%)$ & ${ }^{M C_{p}}=0.860$ \\
\hline Repeated meningitis & $14(10.4 \%)$ & $4(10.3 \%)$ & $3(15 \%)$ & $3(8.1 \%)$ & $2(8 \%)$ & $2(14.3 \%)$ & ${ }^{M C_{p}}=0.860$ \\
\hline Vertigo & $33(24.4 \%)$ & $12(30.8 \%)$ & $6(3 \%)$ & $6(16.2 \%)$ & $5(20 \%)$ & $4(28.6 \%)$ & ${ }^{M} c_{p}=0.55$ \\
\hline Seizures & $17(12.6 \%)$ & $3(7.7 \%)$ & $3(15 \%)$ & $6(16.2 \%)$ & $3(12 \%)$ & $2(14.3 \%)$ & ${ }^{M C_{p}}=0.814$ \\
\hline Paresthesia & $19(14.1 \%)$ & $6(15.4 \%)$ & $3(15 \%)$ & $6(16.2 \%)$ & $3(12 \%)$ & $1(7.1 \%)$ & ${ }^{M C_{p}}=0.943$ \\
\hline
\end{tabular}

MC Monte Carlo

as it was present in $22.8 \%$ (33 patients), paresthesia in $15.2 \%$, while seizures was present in $12.4 \%$ of the studied patients. Recurrent meningitis was reported in $9.7 \%$ of the studied patients while pseudotumor cerebri presented in $9 \%$. Less frequent symptoms were disorientation and cerebrovascular disorders as they were detected only in three, and one patient respectively.

As regards the MEFV genetic mutations, 5 major mutations were detected in most of the studied patients: M694V in 39 patients (26.9\%), M680I in 37 patients (25.5\%), E148Q in 25 patients (17.2\%), V726A in 20 patients (13.8\%), and M694I in 14 patients (9.7\%). These genetic mutations account for $93.1 \%$ (135 patients) of the involved patients.

When a comparative study was done between these five major MEFV gene mutations according to the age of onset of the symptoms, different musculoskeletal and neurological manifestations, ESR, serum amyloid level, and dose of colchicine at the start of the disease and currently no statistically significant difference was found.

\section{Discussion}

This study involved 145 FMF patients (99 adult and 46 pediatric patients). The majority of the studied patients were female $(62.1 \%)$ and this was in line with several studies from Egypt and Israel [11, 25]. Two other studies that were performed on Italian and Arabs showed a similar result [26, 27]. However Amal et al. [28] reported a higher male to female ratio in an Egyptian cohort. A larger sample size may be the cause of this discrepancy. The presenting manifestation in $71.9 \%$ of these patients was abdominal pain followed by musculoskeletal manifestations in $35.2 \%$ in the form of arthralgia, myalgia, and arthritis, to be followed by fever in $30.4 \%$ of patients. This is the same finding of other Egyptian studies [11, 29, 30], while Duşunsel et al. [31] reported that fever was the most common followed by abdominal pain in a cohort of Turkish FMF patients. It seems that the ethnicity of studied patients affects the clinical picture of the attacks.

In the current study, $80.7 \%$ of the studied patients used a colchicine dose of $1.5-3 \mathrm{mg}$ daily. As abdominal pain was the commonest presenting symptom in our study, it was also the major cause of colchicine dose increase. In contrast, a study by Lidar et al. [14] reported that only $40 \%$ of patients used doses higher than $2 \mathrm{mg}$. The different genotype of the studied patients is a major contributing factor for this conflict as the current study included only patients with homozygotic MEFV gene mutation which implies severe disease form.

The current study reported that the most common MEFV genetic mutation was M694V, M680I, E148Q, V726A, and M694I respectively and this is in agreement with several Arab and Turkish studies [30-33]. While a study by Brik et al. [12] showed a lower prevalence of M694V gene mutation in Israeli patients. Different ethnicity of studied patients might be the main cause.

We noted that a large percentage of our studied patients had raised serum Amyloid A, up to (87.9\%) while Amal et al. [28] reported much lower serum Amyloid level (8.4\%). Delay in seeking medical advice, chronicity, severity of the disease, and different sample sizes are major factors for this discrepancy.

Regarding the musculoskeletal manifestations, $38.6 \%$ of the involved patients had arthritis during the period of follow-up. This goes in accordance with two other Egyptian and Turkish studies [30, 34]. While Farag Y et al. [11] and other two Egyptian studies [29, 35] found lower frequency. On the other hand, a Turkish study [36] found a higher frequency of $57 \%$. The period of followup, age of the patients, and chronicity of the disease can affect the frequency of arthritis. The most common joint affection was the knee and ankles, the small joints of the feet, and the hands respectively. This goes in accordance with Farag et al. [11] , Jargour and Dodaki [13] and Lidar $\mathrm{M}$ et al. [14] Monoarthritis was the most frequent pattern of arthritis, being present in $26.9 \%$ (39 patients) of the studied patients. This goes in accordance with many other studies [11, 14, 15, 36]. While Jarjour and Dodaki [13] found diarthritis as the most common pattern in a sample of Syrian FMF patients. No joint deformity was detected in these patients. Many other studies reported that Joint deformity and irreversible joint destruction has been very rarely noted in arthritis of FMF despite its recurrent nature $[11,12,15]$. 
Arthralgia was the most prominent musculoskeletal manifestation presenting in $96.6 \%$ of the studied patients with the knee as the most frequently affected joint, followed by the ankles, feet, and lower back. Other Israeli and Syrian studies reported arthralgia and arthritis as the most common symptoms of FMF patients [12, 13]. The long period of follow-up in the current work probably raised that frequency. Myalgia was present in $19.3 \%$ of the studied patients (28 patients) involving the lower limb muscle(14 patients) and Upper limb muscles(10 patients) with one case of protracted febrile myalgia. Many studies found myalgia to be as frequent as $20-40 \%$ in FMF patients with the same distribution $[17,18]$. While protracted febrile myalgia was reported to occur in 1:3\% of FMF patients in different studies [17, 18, 37].

Regarding neurological manifestation, vertigo was the most common neurological symptom as it was detected in about $22.8 \%$ of the studied patients, followed by paresthesia and seizures. This was in accordance with a recent Iranian publication that detected vertigo in $27.7 \%$ of FMF patients and reported it as a common presentation in FMF [38].

In this study, $15 \%$ of patients had paresthesia. Paresthesia was detected in $22 \%$ of the Iranian FMF cohort, as reported by Salehzadeh et al [39], whereas in Kalyoncu et al's study of 18 Turkish patients with FMF who had neurologic symptoms, $11.1 \%$ had paresthesia [20]. Seizures were detected in 12.4\%. Several researches on EEG abnormalities in FMF patients have been published, however, none of them provide a reliable explanation for the link between FMF and seizures [40-43]. Interestingly, the first link between seizure and FMF was in 1993 when seizures were detected in three Israel patients [44].

Headache was found only in five of our patients which is in contrast with other Iranian and Turkish studies $[38,45]$, while it was detected as a symptom of recurrent meningitis and pseudotumor cerebri and both are present in $9.7 \%$ and $9 \%$ of our patients respectively. The presence of pseudotumor cerebri in conjunction with FMF has been described in the literature [46-48]. Severe headache and meningism may be observed during FMF attacks [48]. A severe type of headache in the form of FMF-like recurring meningitis has also been reported by Feld et al. [40]

When a comparative study was done between these five major MEFV gene mutations according to the age of onset of the symptoms, different musculoskeletal manifestations, ESR, serum amyloid level, and dose of colchicine at the start of the disease and currently, no statistically significant difference was found. This is not in accordance with many previous studies [49-51] that found arthritis and musculoskeletal manifestations related to and more frequent in M649V homozygote mutation but the ethnic and environmental factors must be predominant while dealing with FMF patients. Mohamed Elmalky et al. [52] in a recent study on Egyptian FMF patients, goes partially in accordance with our finding as regard amyloidosis and response to colchicine therapy as they didn't find a correlation between the MEFV gene mutation type and these clinical parameters. However, in a mixed cohort of 220 Arab and Jewish patients with FMF, Gershoni-Baruch et al. [53] noted that homozygosity for M694V, V726A, and E148Q were associated with a severe course and the highest risk for amyloidosis. When a comparative study was done between the five major mutations and different neurological manifestations, no statistically significant difference was found. Unlike this finding, An Israeli study [40] mentioned that most patients with FMF, who experience severe FMF and present with neurologic manifestations had M694V gene mutation. Most of the previous studies compared neurological manifestations in MEFV genepositive and negative patients, which is different from the current work, being concerned with homozygous MEFV gene mutation.

The limitation of the study was the relatively small number of patients included in the study but this was due to the exclusion of patients with heterozygotic gene mutation.

\section{Conclusions}

Musculoskeletal manifestation is the second most common presenting symptom in a cohort of Egyptian FMF patients after abdominal pain. Arthralgia is the most frequent musculoskeletal manifestation while monoarthritis of the knee or ankle joint is the most common pattern of arthritis in FMF patients. Vertigo, paresthesia, and seizures are the most frequent neurological manifestations. Musculoskeletal manifestations, neurological manifestations, serum amyloid level, and dose of colchicine are not related to the type of the genetic mutation in this cohort. Prospective clinical studies with different ethnic groups will help to better clarify the relationship between MEFV gene mutation and disease clinical features. Future research should focus on the musculoskeletal and neurological manifestations, with a larger number of FMF patients undergoing genetic testing and being followed for a longer period of time, including newer therapies.

\section{Abbreviations}

FMF: Familial Mediterranean fever; CNS: Central nervous system; MEFV: Mediterranean fever gene.

\section{Authors' contributions}

All authors have contributed to designing the study, collecting and analyzing, interpretation of data, and preparing and revising the manuscript. Design of the study: MH, SR, Al, AM. Recruitment of patients: SR, Al. Data collection: MH, 
SR, Al, AM. Randomizing : MH, SR, Al, AM. Assessment: MH, SR, Al, AM. Statistical analysis and data interpretation: $\mathrm{MH}, \mathrm{SR}, \mathrm{Al}, \mathrm{AM}$. Manuscript preparation: $\mathrm{MH}, \mathrm{SR}, \mathrm{Al}, \mathrm{AM}$. Manuscript revision: MH, SR, Al, AM. All the authors read and approved the final manuscript.

\section{Funding}

This study has no funding sources.

\section{Availability of data and materials} Available

\section{Declarations}

\section{Ethics approval and consent to participate}

We confirm none of the present study's procedures had violated the principles stated by the latest version of declaration of Helsinki. The protocol of the present study was registered by the local ethics committee with approval code MKSU35-9-21. Written consent from patients was not applicable due to the retrospective nature of the study. We confirm that the manuscript has been read and approved by all the authors, that the requirements for authorship as stated earlier in this document have been met, and that each author believes that the manuscript represents honest work.

\section{Consent for publication}

Not applicable.

\section{Competing interests}

None to declare

\section{Author details}

${ }^{1}$ Gastroenterology, Hepatology and Infectious Diseases Department, Faculty of Medicine, Kafrelsheikh University, Kafrelsheikh, Egypt. ${ }^{2}$ Physical Medicine, Rheumatology and Rehabilitation Department, Faculty of Medicine, Kafrelsheikh University, Kafrelsheikh, Egypt. ${ }^{3}$ Neuropsychiatry Department, Faculty of Medicine, Kafrelsheikh University, Kafrelsheikh, Egypt.

\section{Received: 4 October 2021 Accepted: 9 December 2021}

Published online: 08 February 2022

\section{References}

1. Ozkurede VU, Franchi L (2012) Immunology in clinic review series; focus on autoinflammatory diseases: role of inflammasomes in autoinflammatory syndromes. Clin Exp Immunol 167:382-390

2. Gattorno M, Galeotti C, Caorsi R, Hentgen V (2012). Autoinflammatory syndromes. In: Bijlsma JWJ, editor. EULAR Textbook on Rheumatic Diseases 372-89.

3. Gross O, Thomas CJ, Guarda G, Tschopp J (2011) The inflammasome: an integrated view. Immunol Rev 243:136-151

4. Mankan AK, Kubarenko A, Hornung V (2012) Immunology in clinic review series; focus on autoinflammatory diseases: inflammasomes: mechanisms of activation. Clin Exp Immunol 167:369-381

5. Sarı I, Birlik M, Kasifoğlu T (2014) Familial Mediterranean fever: An updated review. Eur J Rheumatol 1(1):21-33

6. Onen F (2006) Familial Mediterranean fever. Rheumatol Int 26:489-496

7. Kasifoglu T, Cansu DU, Korkmaz C (2009) Frequency of abdominal surgery in patients with familial Mediterranean fever. Intern Med 48:523-526

8. Aharoni D, Hiller N, Hadas-Halpern I (2000) Familial Mediterranean fever: abdominal imaging findings in 139 patients and review of the literature. Abdom Imaging 25:297-300

9. Mor A, Gal R, Livneh A (2003) Abdominal and digestive system associations of familial Mediterranean fever. Am J Gastroenterol 98:2594-2604

10. Ishak GE, Khoury NJ, Birjawi GA, El-Zein YR, Naffaa LN, Haddad MC (2006) Imaging findings of familial Mediterranean fever. Clin Imaging 30:153-159

11. Farag Y, Taher H, Seleem NM, Fahim D, Marzouk H (2020) Articular manifestations in Egyptian children with familial Mediterranean fever. Egypt Rheumatol Rehabil 47:48
12. Brik R, Shinawi M, Kasinetz L, Gershoni-Baruch R (2001) The musculoskeletal manifestations of familial Mediterranean fever in children genetically diagnosed with the disease. Arthritis Rheum 44:1416-1419

13. Jarjour RA, Dodaki R (2011) Arthritis patterns in familial Mediterranean fever patients and association with M694V mutation. Mol Biol Rep 38:2033-2036

14. Lidar M, Kedem R, Mor A, Levartovsky D, Langevitz P, Livneh A (2005) Arthritis as the sole episodic manifestation of familial Mediterranean fever. J Rheumatol 32:859-862

15. Ince E, Cakar N, Tekin M, Kendirli T, Ozkaya N, Akar N et al (2002) Arthritis in children with familial Mediterranean fever. Rheumatol Int 21:213-217

16. Uthman I (2005) The arthritis of familial Mediterranean fever. J Rheumatol $32: 2278$

17. Tunca M, Akar S, Onen F, Ozdogan H, Kasapcopur O, Yalcinkaya F et al (2005) Familial Mediterranean fever (FMF) in Turkey: results of a nationwide multicenter study. Medicine (Baltimore) 84:1-11

18. Majeed HA, Al-Qudah AK, Qubain H, Shahin HM (2000) The clinical patterns of myalgia in children with familial Mediterranean fever. Semin Arthritis Rheum. 2000(30):138-143

19. Varghese A, Thomas J, Maramattom BV (2021) 'More Than Just Skin in the Game'. DADA2 Autoinflammatory Syndrome and Stroke in the Young. Ann Indian Acad Neurol 24(3):410-412

20. Kalyoncu U, Eker A, Oguz KK, Kurne A, Kalan I, Akif M et al (2010) Familial Mediterranean fever and central nervous system involvement: a case series. Medicine (Baltimore) 89(2):75-84

21. Ben-Chetrit E, Touitou I (2009) Familial mediterranean Fever in the world. Arthritis Rheum 61:1447-1453

22. Ozen S (2009) Changing concepts in familial Mediterranean fever: is it possible to have an autosomal-recessive disease with only one mutation? Arthritis Rheum 60:1575-1577

23. Booty MG, Chae JJ, Masters SL, Remmers EF, Barham B, Le JM et al (2009) Familial Mediterranean fever with a single MEFV mutation: where is the second hit? Arthritis Rheum 60:1851-1861

24. Berkun Y, Eisenstein EM (2014) Diagnostic criteria of familial Mediterranean fever. Autoimmun Rev 13(4-5):388-390

25. Lidar M, Tokov I, Chetrit A, Zaks N, Langevitz P, Livneh A (2005) Diagnosis delay in familial Mediterranean fever (FMF): social and gender gaps disclosed. Clin Exp Rheumatol 23(3):357-363

26. La Regina M, Nucera G, Diaco M, Procopio A, Gasbarrini G, Notarnicola C et al (2003) Familial Mediterranean fever is no longer a rare disease in Italy. European Journal of Human Genetics 11(1):50-56

27. Grateau G, Pêcheux C, Cazeneuve C, Cattan D, Dervichian M, Goossens M et al (2000) Clinical versus genetic diagnosis of familial Mediterranean fever. QJM: Monthly Journal of the Association of Physicians 93(4):223-229

28. Amal R. Mansour, Ayman El-Shayeb, Nihal El Habachi, Mohamad A. Khodair, Doaa Elwazzan, Nermeen Abdeen, et al (2019). Molecular Patterns of MEFV Gene Mutations in Egyptian Patients with Familial Mediterranean Fever: A Retrospective Cohort Study, International Journal of Inflammation Article ID 2578760, 5 pages.

29. Lofty HM, Marzouk H, Farag Y, Nabih M, Khalifa IA, Mostafa N, Salah A et al (2016) Serum Amyloid A Level in Egyptian Children with Familial Mediterranean Fever. Int. J Rheumatol 7354018

30. Salah S, Talaat HS, El Basha NR, Marzouk H, AbdElhamid S, Shafie ES (2017) Comparing D-dimer status in children with familial Mediterranean fever during and in between acute attacks. Egypt Rheumatol 40(2):107-110

31. Dusunsel R, Dursun I, Gündüz Z, Poyrazoglu MH, Gürgöze MK, Dundar M (2008) Genotype - phenotype correlation in children with familial Mediterranean fever in a Turkish population. Pediatr Int 50:208-212

32. Dundar M, Emirogullari EF, Kiraz A, Taheri S, Baskol M (2011) Common familial Mediterranean fever gene mutations in a Turkish cohort. Molecular Biology Reports 38(8):5065-5069

33. Majeed HA, El-Shanti H, Al-Khateeb MS, Rabaiha ZA (2002) Genotype/ phenotype correlations in Arab patients with familial Mediterranean fever. Semin Arthritis Rheum 31 (6):371-376

34. Yilmaz R, Karaaslan E, Ozer S, Sonmezgoz E, Kazanci N, Cakan N et al (2014) Hypovitaminosis D in children with familial Mediterranean fever. Clin Invest Med 37:211-216

35. Settin A, El-Baz R, AbdRasool M, El-Khalegy H, El-Sayed O, El-Bendary M (2007) Clinical and molecular diagnosis of familial Mediterranean fever in Egyptian children. J Gastrointestin Liver Dis 16:141-145 
36. Barut K, Sahin S, Adrovic A, Sinoplu AB, Yucel G, Pamuk G (2018) Familial Mediterranean fever in childhood: a single-center experience. Rheumatol Int 38(1):67-74

37. Odabas AR, Cetinkaya R, Selcuk Y, Bilen H (2002) Familial Mediterranean fever. South Med J 95:1400-1403

38. Salehzadeh F, Azami A, Motezarre M, Nematdoust Haghi R, Ahmadabadi F (2020) Neurological Manifestations in Familial Mediterranean Fever: a Genotype-Phenotype Correlation Study. Open Access Rheumatol 12:15-19

39. Salehzadeh F, Emami D, Zolfegari AA, Yazdanbod A, Habibzadeh S, Bashardost B et al (2008) Familial mediterranean fever in northwest of Iran (Ardabil): the first global report from Iran. Turk J Pediatr 50(1):40-44

40. Feld O, Yahalom G, Livneh A (2012) Neurologic and other systemic manifestations in FMF: published and own experience. Best Pract Res Clin Rheumatol 26(1):119-133

41. Gentiloni N, Gabbrielli N, Caradonna P, Schiavino D, Anti M, David M et al (1992) Familial Mediterranean fever and electroencephalographic changes. A clinical case [in Italian]. Minerva Med 83(5):307-310

42. Fedorova ML (1979) Neurologic manifestations of periodic disease [in Russian]. Zh Nevropatol Psikhiatr Im S S Korsakova 79(7):912-917

43. Eliakim M, Bental E (1961) Recurrent polyserositis ("periodic disease"). Electroencephalographic changes. Arch Intern Med 108:91-99

44. Gedalia A, Zamir S (1993) Neurologic manifestations in familial mediterranean fever. Pediatr Neurol 9(4):301-302

45. Canpolat M, Gumus H, Gunduz Z, Dusunsel R, Kumandas S, Bayram AK et al (2017) Neurological Manifestations in Familial Mediterranean Fever: Results of 22 Children from a Reference Center in Kayseri, an Urban Area in Central Anatolia, Turkey. Neuropediatrics 48:79-85

46. Per H, Canpolat M, Gümüş H (2013) Clinical spectrum of the pseudotumor cerebri in children: etiological, clinical features, treatment and prognosis. Brain Dev 35(6):561-568

47. Feld O, Yahalom G, Livneh A (2012) Neurologic and other systemic manifestations in FMF: published and own experience. Best Pract Res Clin Rheumatol 26(1):119-133

48. Yigit S, Karakus N, Kurt SG, Ates O (2013) Association of missense mutations of Mediterranean fever (MEFV) gene with multiple sclerosis in Turkish population. J Mol Neurosci 50(2):275-279

49. Brik R, Shinawi M, Kepten I, Berant M, Gersoni-Baruch R (1999) Familial Mediterranean fever: clinical and genetic characterization in a mixed pediatric population of Jewish and Arab patients. Pediatrics [article online] 103:e70

50. Yalcinkaya $F(2000)$. Spectrum of FMF mutations in Turks. In: Familial Mediterranean Fever II International Conference [lectures and abstracts] May 3-7; Antalya, Turkey; p. 34-5.

51. Langevitz P, Sidi G, Livneh A, Shinar Y, Pras M, Pras E (2000). Protracted febrile myalgia of FMF: mutation analysis and clinical features [abstract]. In: Familial Mediterranean Fever II International Conference May 3-7; Antalya, Turkey; p. 83.

52. Almalky M, Amir R, Baz EG (2021) Genotype Phenotype Correlation of FMF Cases in East Delta of Egypt: 2 Years of Follow-up. Egyptian J Hospital Med 83:1149-1154

53. Gershoni-Baruch R, Shinawi M, Leah K, Badarnah K, Brik R (2001) Familial Mediterranean fever: prevalence, penetrance and genetic drift. Eur J Hum Genet 9(8):634-637

\section{Publisher's Note}

Springer Nature remains neutral with regard to jurisdictional claims in published maps and institutional affiliations.

\section{Submit your manuscript to a SpringerOpen ${ }^{\circ}$ journal and benefit from:}

- Convenient online submission

- Rigorous peer review

- Open access: articles freely available online

- High visibility within the field

- Retaining the copyright to your article

Submit your next manuscript at $\boldsymbol{\nabla}$ springeropen.com 